\title{
Penggunaan Pelarut Etanol dan Aseton pada Prosedur Kerja Ekstraksi Total Klorofil Daun Jati (Tectona grandis) dengan Metode Spektrofotometri
}

\author{
Sumiati ${ }^{1}$ \\ 1Universitas Islam Negeri Walisongo Semarang. Email: sumiati@walisongo.ac.id
}

Submisi: 21 April 2021; Penerimaan: 28 Mei 2020

\begin{abstract}
ABSTRAK
Penelitian ini bertujuan untuk mengetahui kadar total klorofil pada daun jati yang diekstraksi menggunakan pelarut etanol dan aseton, dan untuk mengetahui perbedaan kadar total klorofil pada daun jati yang diekstraksi menggunakan pelarut etanol dan aseton. Berdasarkan hasil analisis kadar klorofil pada ekstraksi daun jati menggunakan metode Spektrofotometri pada pelarut etanol diperoleh hasil kadar klorofil a adalah 31,437 mg/L dan klorofil b sebesar 27,468 mg/L, sedangkan untuk pelarut aseton diperoleh hasil kadar klorofil a adalah 35,279 mg/L dan klorofil b sebesar $27,640 \mathrm{mg} / \mathrm{L}$. Kadar total klorofil pada daun jati dengan pelarut etanol diperoleh hasil sebesar $=59,138 \mathrm{mg} / \mathrm{L}$, dan untuk pelarut aseton diperoleh hasil $62,900 \mathrm{mg} / \mathrm{L}$. Hasil penelitian menunjukkan pelarut aseton merupakan pelarut yg baik untuk ekstraksi daun jati.
\end{abstract}

Kata kunci: Daun jati; etanol; aseton; kadar total klorofil

\section{LATAR BELAKANG}

Fisiologi tumbuhan merupakan salah satu mata kuliah praktikum yang di ikuti oleh mahasiswa. Fisiologi tumbuhan adalah ilmu yang mempelajari proses metabolisme pada tumbuhan (Ziharsya Iqbal, 2019). Dengan adanya mata kuliah praktikum fisiologi tumbuhan ini diharapkan mahasiswa bisa mendapatkan wawasan dan pengetahuan, serta memahami proses fisiologi yang terjadi pada tumbuhan. Salah satu materi yang di lakukan pada praktikum fisiologi tumbuhan adalah analisis kadar total klorofil dengan metode spektrofotometer.

Klorofil merupakan pigmen pada tanaman berwarna hijau yang memiliki peran penting pada proses fotosintesis. Pada tanaman tingkat tinggi, lumut, alga, pakis, dan organisme prokariota memiliki pigmen pelengkap yang terdiri dari klorofil a dan klorofil b. (Gross, 1987, Lichtenthaler, 1987, Gross,1991, Scheer, 1991, Scheer 1991, Scheer,2006, Junet
F. da Costa dkk, 2009). Klorofil dapat larut dalam eter, kloroform, bensol, metanol, etanol dan aseton, akan tetapi klorofil tidak dapat larut dalam air (Ajiningrum P.S., 2018).

Dalam penelitian ini, tanaman yang akan digunakan untuk ekstraksi pigmen klorofil adalah tanaman jati. Tanaman Jati (Tectona grandis) adalah tanaman yang tumbuh di daerah beriklim tropis contohnya di Indonesia. Tanaman jati memiliki daun yang berbentuk bulat telur atau oval, panjang daun $13-75 \mathrm{~cm}$, lebar daun $10-49 \mathrm{~cm}$, tajuknya berbentuk rimbun, dan ujung daun tumpul ( Ariyanto, 2006). Kandungan pigmen alami yang terdapat pada daun jati adalah pelargonidin 3-glukosida, pelargonidin 3,7-diglukosida, klorofil, pheophiptin, $\beta$-karoten, dan dua pigmen lain yang belum teridentifikasi (Nur Edi Didik dkk., 2018). Daun jati merupakan salah satu tanaman yang mengandung pigmen klorofil (Bapa Lasang Muharam 
2017). Agar mahasiswa mendapatkan wawasan, pengetahuan dan memahami materi praktikum "Analisa Kadar Total Klorofil", maka diperlukan penelitian tentang ekstraksi tanaman menggunakan pelarut yang sesuai pada analisa kadar total klorofil dengan metode spektrofotometer.

\section{METODE PENELITIAN}

\section{Alat dan Bahan}

Alat yang digunakan adalah seperangkat alat gelas, neraca analitik, dan Spektrofotometer UV - Vis Double Beam Aquamate 8000 Thermo Scientific .Bahan yang digunakan adalah daun jati yang masih segar dan berwarna hijau yang diambil dari lingkungan gedung $Q$ UIN Walisongo Semarang, etanol absolut PA merek Merck, aseton PA merek Mallinckrodt.

\section{Ekstraksi Daun Jati}

Sebelum diekstraksi daun jati dibersihkan dengan menggunakan air bersih, kemudian daun dipotong kecilkecil dan selanjutnya dikeringanginkan. Sampel daun jati ditimbang masingmasing sebanyak 5 gram. Sampel yang telah ditimbang kemudian dimaserasi dengan menggunakan pelarut sebanyak $100 \mathrm{~mL}$ selama $3 \times 24$ jam atau sampai terlarut. Dalam penelitian ini, pelarut yang digunakan adalah etanol dan aseton. Setelah dilakukan maserasi, selanjutnya filtrat disaring menggunakan kertas saring.

\section{Analisa Kadar Klorofil}

Prosedur kerja untuk analisis kadar klorofil menggunakan alat spektrofotometer adalah mengkalibrasi spektrofotometer terlebih dahulu terhadap nilai transmitansinya. Nilai transmitan pelarut diatur atau dibuat $100 \%$, sehingga nilai absorbansi yang dihasilkan saat pengukuran sematamata ditentukan oleh klorofil sebagai zat terlarutnya (bukan oleh pelarut), kemudian larutan klorofil dimasukkan ke dalam kuvet sampai tanda batas dan selanjutnya diukur absorbansinya pada panjang gelombang $649 \mathrm{~nm}$ dan $665 \mathrm{~nm}$ (Metode Wintermans and De Mots) (Ajiningrum. P.S., 2018) untuk pelarut etanol, dan panjang gelombang 645 dan $663 \mathrm{~nm}$ ( Metode Arnon) untuk pelarut aseton ( Suyitno, 2010). Rumus untuk menghitung kadar klorofil a, kadar klorofil b dan kadar total klorofil sebagai berikut:

Kadar klorofil dengan pelarut etanol dihitung dengan rumus Wintermans dan De Mots :

$$
\begin{aligned}
& \text { Klorofil a }\left(\frac{m g}{L}\right)= \\
& (13,7 \times O D 665)-(5,76 \times O D 649) \\
& \text { Klorofil b }\left(\frac{m g}{L}\right)= \\
& (25,8 \times O D 649)-(7,7 \times O D 665)
\end{aligned}
$$

Total Klorofil $\left(\frac{m g}{L}\right)=$ $(20 \times O D 649)+(6,1 \times O D 665)$

Kadar klorofil dengan pelarut aseton dihitung dengan rumus Arnon :

$$
\begin{aligned}
& \text { Klorofil a }\left(\frac{m g}{L}\right)= \\
& (12,7 \times O D 663)-(2,69 \times O D 645) \\
& \text { Klorofil b }\left(\frac{m g}{L}\right)= \\
& (22,9 \times \text { OD } 645)-(4,68 \times O D 663) \\
& \text { Total Klorofil }\left(\frac{m g}{L}\right)= \\
& (20,2 \times \text { OD } 645)+(8,02 \times O D 663)
\end{aligned}
$$

\section{HASIL DAN PEMBAHASAN}

Klorofil merupakan pigmen pada tanaman berwarna hijau yang memiliki peran penting pada proses fotosintesis. Klorofil dapat larut dalam metanol, etanol, aseton, eter, kloroform dan bensol, tetapi klorofil tidak dapat larut dalam air. Teknik spektrofotometer merupakan sebuah teknik untuk pemisahan klorofil a dan klorofil b dan pigmen - pigmen lainnya. Sifat fisik 
klorofil adalah menerima dan atau memantulkan cahaya dengan gelombang yang berlainan. Klorofil banyak menyerap sinar dengan panjang gelombang antara 400-700 nm, terutama sinar merah dan biru (Adi Prastyo, Kurniawan dan Ainun Nikmati Laily, 2015).

Klorofil a dan klorofil b terdapat pada sebagian besar tumbuhan khususnya tumbuhan tingkat tinggi (Fajar Ahmad dkk, 2014). Klorofil yang berperan dalam reaksi perubahan energi radiasi matahari menjadi energi kimia serta menyerap dan mengangkut energi ke pusat reaksi molekul adalah klorofil a, sedangkan klorofil b berperan sebagai penyerap energi matahari yang diteruskan ke klorofil a (Mashud. N. dan
Farida Octavia, 2015). Klorofil adalah pigmen yang menyerap sinar radiasi elektromagnetik pada spektrum kasat mata (visibel) seperti sinar matahari ( Kimball. J.W., 1983, Nur Eka Putri, Oreza. 2019). Spektrofotometer adalah alat yang digunakan untuk mengukur kandungan klorofil (Sumenda Lusiana dkk, 2011).

Berdasarkan hasil analisis kadar klorofil pada ekstraksi daun jati dengan pelarut etanol dan aseton diperoleh nilai OD sebagaimana tercantum pada Tabel 1 dan Tabel 2. Data hasil analisis kadar klorofil a, klorofil b dan total klorofil pada ekstraksi daun jati menggunakan pelarut etanol dan aseton dapat dilihat pada tabel 2.

Tabel 1. Nilai OD atau nilai absorbansi klorofil pada daun jati menggunakan pelarut etanol dan aseton

\begin{tabular}{lllllll}
\hline \multirow{2}{*}{ Jenis Pelarut } & Berat Daun & Volume Pelarut & \multicolumn{2}{l}{ Nilai OD } \\
& & & $645 \mathrm{~nm}$ & $649 \mathrm{~nm}$ & $663 \mathrm{~nm}$ & $665 \mathrm{~nm}$ \\
\hline Etanol & $5 \mathrm{gram}$ & $100 \mathrm{~mL}$ & & 2,001 & & 3,136 \\
Aseton & $5 \mathrm{gram}$ & $100 \mathrm{~mL}$ & 1,855 & & 3,171 & \\
\hline
\end{tabular}

Tabel 2. Kadar klorofil a, Klorofil b dan Total Klorofil Pada Daun Jati dengan Pelarut Etanol dan Aseton

\begin{tabular}{llll}
\hline \multirow{2}{*}{ Pelarut } & \multicolumn{2}{l}{ Kadar Klorofil $(\mathrm{mg} / \mathrm{L})$} & \\
& Klorofil a & Klorofil b & Total Klorofil \\
\hline Etanol & 31,437 & 27,468 & 59,138 \\
Aseton & 35,279 & 27,640 & 62,900 \\
\hline
\end{tabular}

Dari analisis kadar klorofil pada ekstraksi daun jati dengan menggunakan pelarut etanol diperoleh hasil kadar klorofil a adalah $31,437 \mathrm{mg} / \mathrm{L}$ dan klorofil b sebesar 27,468 mg/L, sedangkan untuk pelarut aseton diperoleh hasil kadar klorofil a adalah $35,279 \mathrm{mg} / \mathrm{L}$ dan klorofil b sebesar $27,640 \mathrm{mg} / \mathrm{L}$. Perhitungan kadar klorofil a dan kadar klorofil b menunjukkan nilai terbesar kadar klorofil pada daun jati terdapat pada klorofil a. Menurut Dwidjoseputro (1980:78) pada semua tumbuhan hijau terdapat Klorofil a dan klorofil b dengan perbandingan 3:1 pada tumbuhan tinggi. Kondisi pertumbuhan dan faktor lingkungan bisa mempengaruhi Perbandingan jumlah Klorofil a dan klorofil b ( Gross, 1991).

Menurut Andriani, L.L. (2014), Eko Novitasari Anik dan Robiatul Adawiyah (2018), mengemukakan bahwa pelarut campuran aseton dan alkohol lebih banyak melarutkan klorofil a dari pada klorofil b. Berdasarkan struktur kimianya, klorofil a bersifat kurang polar atau 
bahkan sering digolongkan sebagai senyawa non polar, sedangkan klorofil b bersifat polar. Rahayuningsih dkk, (2018), Indrasti Dias dkk (2019) juga mengemukakan bahwa klorofil a dan klorofil $b$ adalah dua jenis klorofil yang terdapat pada tanaman. Klorofil a bersifat kurang polar, berwarna biru hijau dan mempunyai gugus metil $\left(\mathrm{CH}_{3}\right)$, sedangkan klorofil $b$ bersifat polar, berwarna kuning hijau dan mengikat gugus formil (CHO). Struktur Klorofil dapat di lihat pada gambar 1. Analisis kadar total klorofil pada ekstraksi daun jati dengan menggunakan pelarut etanol dan aseton dapat ditampilkan pada diagram batang pada gambar 2 .

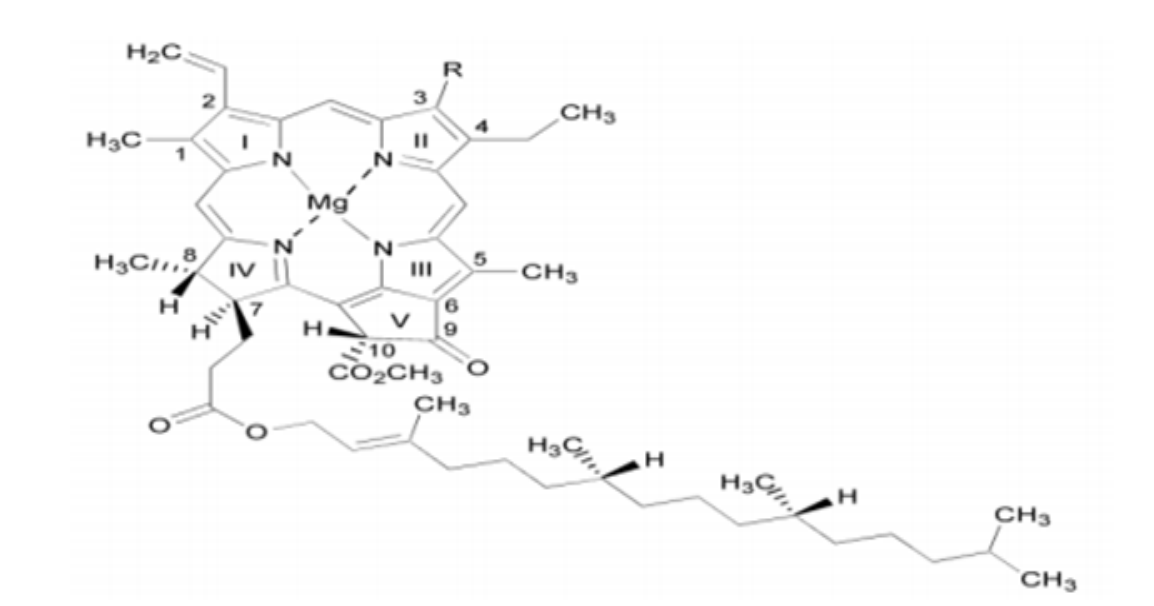

Gambar 1. Struktur Klorofil ( klorofil a ( $\mathrm{R}-\mathrm{CH}_{3}$ ) dan klorofil b (R-CHO) (Indrasti Dias dkk , 2019)

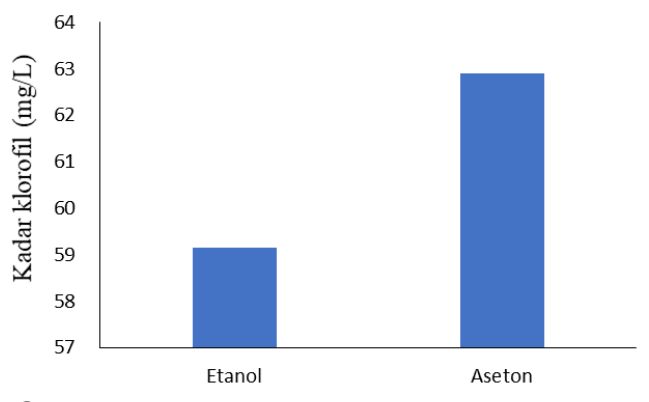

Gambar 2. Diagram Batang Kadar Total

Klorofil Pada Ekstraks Daun Jati

Berdasarkan hasil penelitian ekstraksi daun jati yang telah dilakukan, kadar total klorofil yang menggunakan pelarut aseton sebesar $62,902 \mathrm{mg} / \mathrm{L}$, sedangkan kadar total klorofil yang menggunakan pelarut etanol sebesar $59,130 \mathrm{mg} / \mathrm{L}$. Hal ini menunjukkan bahwa kadar total klorofil yang dihasilkan pelarut aseton lebih besar dari pelarut etanol. Hasil penelitian Andriani. L.L, (2014) juga mengemukakan bahwa total klorofil tertinggi ekstraksi daun katuk diperoleh pada pelarut aseton yaitu $41,1074 \mathrm{mg} / \mathrm{L}$ dan terendah diperoleh pada pelarut etanol yaitu $18.6435 \mathrm{mg} / \mathrm{L}$. Putri W.D.R. dkk, (2003) dalam penelitiannya mengemukakan bahwa hasil total klorofil terbesar pada ekstrak daun suji diperoleh pada pelarut aseton $85 \%$ yaitu $12,03 \mathrm{mg} / \mathrm{L}$. Sedangkan pada pelarut etanol $85 \%$ diperoleh hasil 10,25 $\mathrm{mg} / \mathrm{L}$. Perbedaan jenis pelarut akan menimbulkan perbedaan terhadap total klorofil.

\section{KESIMPULAN}

Berdasarkan hasil penelitian pada ekstraksi daun jati dengan menggunakan pelarut etanol diperoleh kadar klorofil a adalah $31,437 \mathrm{mg} / \mathrm{L}$ dan klorofil $b$ sebesar $27,468 \mathrm{mg} / \mathrm{L}$, sedangkan untuk pelarut aseton diperoleh kadar klorofil a 
adalah $35,279 \mathrm{mg} / \mathrm{L}$ dan klorofil $\mathrm{b}$ sebesar $27,640 \mathrm{mg} / \mathrm{L}$. Kadar total klorofil pada ekstraksi daun jati dengan menggunakan pelarut etanol diperoleh hasil sebesar $=59,138 \mathrm{mg} / \mathrm{L}$, dan untuk pelarut aseton diperoleh hasil sebesar $62,900 \mathrm{mg} / \mathrm{L}$. Hasil penelitian menunjukkan bahwa pelarut aseton merupakan pelarut yg baik untuk ekstraksi daun jati.

\section{DAFTAR PUSTAKA}

Adi Prastyo, Kurniawan, Ainun Nikmati Laily. 2015. Uji Konsentrasi Klorofil Daun Temu Mangga (Curcuma mangga Val.), Temulawak (Curcuma xanthorrhiza), dan Temu Hitam (Curcuma aeruginosa) dengan Tipe Kertas Saring yang Berbeda Menggunakan Spektrofotometer. Seminar Nasional Konservasi dan Pemanfaatan Sumber Daya Alam Pendidikan Biologi, Pendidikan Geografi, Pendidikan Sains, PKLH - FKIP UNS.

Ajiningrum,P.S. 2018. Kadar Total Pigmen Klorofil Tanaman Avicennia marina Pada Tingkat Perkembangan Daun yang Berbeda. Stigma 11(2): 52-59; September 2018. ISSN: $1412-$ 1840. e-ISSN: 2621 - 9093.

Andriani. L.L, 2014. Pengaruh Jenis Pelarut Dan Uji Stabilitas Warna Pada Ekstraksi Klorofil Daun Katuk (Sauropus androgynus). Politeknik Negeri Sriwijaya Jurusan Teknik Kimia. Palembang. Skripsi.

Ariyantoro, H. 2006. Budidaya Tanaman Kehutanan. PT. Citra Aji Parama.Yogyakarta.

Bapa Lasang, Muharam. 2017. Ekstraksi Zat Warna Daun Jati (Tectona grandis) dan Aplikasinya Pada Dyen Sensitized Solar Cell (Dssc). Fakultas Sains Dan Teknologi. Universitas Islam Negeri Alauddin Makassar. Skripsi.

Dwidjoseputro, D. 1980. Pengantar Fisiologi Tumbuhan. Jakarta: Gramedia
Eko Novitasari, Anik dan Robiatul Adawiyah. 2018. Perbandingan Pelarut Pada Ekstraksi Total Klorofil Daun Mangkokan dengan Metode Spektrofotometri. Jurnal Sains Vol.8 No.15 (2018). Issn 2087-0725

Fajar, Ahmad, Ratna Ibrahim, dan Eko Nurcahaya Dewi. 2014. Stabilitas Ekstrak Kasar Pigmen Klorofil, Beta Karoten, dan Caulerpin Alga Hijau (Caulerpa racemosa) pada Suhu Penyimpanan yang Berbeda. Jurnal Pengolahan dan Bioteknologi Hasil Perikanan. Vol $3(1)$.

Gross J. 1991. Pigments In Vegetables Chlorophylls and Carotenoids. New York: Van Nostrand Reinhold.

Gross, J. 1987. Pigments in Fruits. London: Kluwer Academic Publisher

Indrasti, Dias, Nuri Andarwulan, Eko Hari Purnomo, Nur Wulandari. 2019. Klorofil Daun Suji: Potensi dan Tantangan Pengembangan Pewarna Hijau Alami. Jurnal IImu Pertanian Indonesia (JIPI). ISSN 0853-4217. EISSN 2443-3462.

Junet. F. da Costa, Ferry F. Karwur , dan Leenawaty Limantara, 2009. Efek Beta Karoten dan Agregasi Klorofil Pada Fotostabilitas Klorofil a dalam Pelarut Aseton. Jurnal Natur Indonesia 11(2), April 2009: 115123. ISSN 1410-9379, Keputusan Akreditasi No 65A/DIKTI/Kep./2008.

Kimball, J. W. 1983. Biologi. Jakarta: Erlangga.

Lichtenthaler, K. H. 1987. Methods in Enzymology. Chlorophyll and Carotenoid: Pigments of Photosynthetic Biomembranes. New York: Academic Press.Inc.

Mashud, N. dan Farida Octavia, 2015. Karakteristik Fisiologi Daun Aren Varietas Akel Toumung. Jurnal B. Palma. Vol.16(1).

Nur Edi, Didik, M. Halim Natsir2, dan Irfan Djunaidi. 2018. Pengaruh penambahan ekstrak daun jati (Tectona grandis linn. F) dalam pakan terhadap performa ayam 
petelur. Jurnal Nutrisi Ternak Tropis Vol 1 No 1 pp 34-44.

Nur Eka Putri, Oreza. 2019. Analisis Kandungan Klorofil Dan Senyawa Antosianin Daun Pucuk Merah (Syzygium oleana) Berdasarkan Tingkat Perkembangan Daun Yang Berbeda. Fakultas Tarbiyah Dan Keguruan. Universitas Islam Negeri Raden Intan Lampung. Skripsi

Putri, W.D.R., Zubaidah, E., dan Sholahudin, N. 2003. Ekstraksi pewarna alami daun suji, kajian pengaruh blanching dan jenis bahan pengekstrak. Jurnal Teknologi Pertanian Vol. IV (1) : 13 $-24$.

Rahayuningsih E, Pamungkas MS, Olvianas M, Putera ADP. 2018. Chlorophyll extraction from suji leaf (Pleomele angustifolia Roxb.) with $\mathrm{ZnCl} 2$ stabilizer. Journal of Food Science and Technology. 55(3): 1.036. https://doi.org/10.1007/s13197017--1.028 3016-7

Scheer, H. 2006. An overview of chlorophylls and bacteriochlorophylls:

biochemistry, biophysics, function and apllications. Di dalam: Grimm, B., Porra, R. Rüdiger, W. \& Scheer, H (ed). Chlorophyll and Bacteriochlorophyll: Biochemistry, Biophysics, Function and Apllications. Netherlands: Springer Scheer, H., 1991. Chlorophylls. USA: CRC Press, Inc.

Sumenda, Lusiana, dkk, 2011. "Analisis Kandungan Klorofil Daun Mangga (Mangifera indica L.) pada Tingkat Perkembangan Daun yang Berbeda", Jurnal Bios Logos, 1(1). Suyitno. 2010. Determinasi Pigmen Dan Pengukuran Kandungan Klorofil Daun. Materi: Pelatihan Guru-guru Biologi RSBI D.I.Y. di Jurdik. Biologi FMIPA UNY.

Ziharsya, lqbal. 2019. Analisis Kandungan Klorofil Tumbuhan Biduri (Calotropis gigantea L.) berdasarkan Faktor Fisik dan Kimia Di Kawasan Geothermal

\author{
dengan Pesisir Pantai Sebagai \\ Pengembangan Praktikum \\ Fisiologi Tumbuhan__Fakultas \\ Tarbiyah Dan Keguruan \\ Universitas Islam Negeri Ar-Raniry \\ Banda Aceh. Skripsi.
}

